\title{
UPPER PALEOZOIC TRACE FOSSILS FROM THE TRANSANTARCTIC MOUNTAINS AS INDICATORS OF GONDWANA PALEOCLIMATE
}

MILLER*, Molly F. Dept. of Geology, Vanderbilt Univ.. Nashville. TN 37235.

U.S.A.; ISBELL, John L., Dept. of Geosciences, University of Wisconsin.

Milwaukee. WI 53201, U.S.A.; SMAIL, Stephen E.. Dept. of Geology. Vanderbilt Univ., Nashville. TN 37235, U.S.A.; GILLER, Susan, Hydrosphere Data Products Inc., Boulder, CO 80302, U.S.A.

Biogenic structures found during the 1995-96 field season in Upper Carboniferous to Permian deposits of the Shackleton Glacier area, Antarctica, give new information about the late Paleozoic climate of the Panthalassan margin of Gondwana. The sequence consists of Upper Carboniferous to Lower Permian glacigenic deposits dominated by tillites (Pagoda Formation) overlain by Lower Permian post-glacial shale deposited by lacustrine turbidite systems (Mackellar Formation). This is conformably overlain by Lower Permian deltaic-fluvial sandstones (Fairchild Formation).

Invertebrate body fossils are absent from the sequence. At one locality a thin $(<10 \mathrm{~m})$ siltstone unit just above the base of the tillite records deposition in a small shallow lake. Trace fossils that are found in the nonmarine Mackellar and Fairchild Formations also occur in these siltstones and demonstrate a glacial-lacustrine vs. glacial-marine setting. Isolated horizons are extensively burrowed, indicating that at times animal activity overshadowed physical reworking and suggesting multiple colonization events.

Therefore the lake was sufficiently large and long-lasting to support establishment (and perhaps repeated establishment) of a benthic infauna.

During this time, approximately $280 \mathrm{Ma}$, the South Pole was located in the Central Transantarctic Mountains, in the vicinity of the Shackleton Glacier area. The paleogeographic position of the area near the pole combined with the occurrence of the biogenic structures at the base of the glacial section suggests that periods of warming sufficient to allow development of burrowing faunas in shallow lakes occurred during late Paleozoic glaciation even at polar latitudes.

Biogenic structures also constrain paleoclimatic conditions during deposition of the slightly younger (late Early to early Late) Permian coal-bearing siliciclastic rocks (Buckley Formation) that conformably overly the glacial and post-glacial lacustrine and fluvio-delatic deposits. The paleoclimate previously was interpreted as temperate and fluctuating based on paleobotanical information, but recent discovery of dropstones suggests ice cover and more frigid conditions. However, because trace fossils occur in profusion within a few centimenters stratigraphically of the dropstones, the dropstones are best interpreted as a result of sproadic (?seasonal) ice movement and melting rather than as reflecting permanent ice cover.

In summary, biogenic structures allow higher resolution interpretation of late Paleozoic high latitude Gondwana paleoclimates than is otherwise possible. The emerging picture is of occasional climate amelioration even near the pole during Late Carboniferous - Early Permian glaciation, and of continuation of cold conditions into the Late Permian. 